\title{
Reflections from the Field: Disparate responses to labour exploitation in post-Katrina Louisiana
}

\author{
Leanne McCallum
}

\section{Abstract}

Hurricane Katrina was a devastating natural disaster that changed the landscape of the United States' Gulf Coast. This was followed by a human-made disaster of failed policies, poor governmental oversight, and rampant labour abuse. This article compares how the anti-trafficking and labour rights movements responded to the widespread labour abuse following Katrina. It examines how the worker rights movement responded to systemic issues impacting labourers, and explores the anti-trafficking movement's criminal justice response to severe forms of exploitation. It shows how the anti-trafficking movement failed to adequately address severe forms of labour abuse, as opposed to the more successful organising efforts of the worker rights movement. The article concludes by considering how the two movements may respond to conditions of labour exploitation emerging as a result of a new disaster impacting workers in Louisiana: the COVID-19 pandemic.

Keywords: labour exploitation, Louisiana, Hurricane Katrina, worker rights movement, anti-trafficking movement, disaster response

Please cite this article as: L McCallum, 'Reflections from the Field: Disparate responses to labour exploitation in post-Katrina Louisiana', Anti-Trafficking Review, issue 15, 2020, pp. 21-41, https://doi.org/10.14197/atr.201220152.

In August 2005, Hurricane Katrina devastated the United States' Gulf Coast. After the storm passed, a human-made disaster of labour protection deregulation, poor governmental oversight, and racial tension created a 'perfect storm' of conditions for pervasive labour exploitation. This article explores these conditions of labour exploitation in Louisiana in the decade after Hurricane Katrina, with a specific focus on two movements that developed during that time: the worker rights movement and the anti-trafficking movement. The article opens with an introduction to the genesis of these movements in the post-Katrina context. It then analyses these two movements through the lens

This is an open-access article distributed under the terms of the Creative Commons Attribution License (CC-BY). Under the CC-BY license, the public is free to share, adapt, and make commercial use of the work. Users must always give proper attribution to the authors and the Anti-Trafficking Review. 
of their response to key conditions that enabled widespread labour abuses: labour protection suspension, enforcement failures, political tension, and racial strife. It explores how a grassroots worker rights movement blossomed in the post-Katrina context and fostered multi-ethnic worker-led efforts to combat labour exploitation. It also considers how the criminal justice-focused antihuman trafficking movement, which began around the same time, failed to adequately counter labour exploitation. The article then reflects on the lessons to be drawn from these movements during the post-Katrina era, and considers current barriers to collaboration between them. It concludes with a consideration of how those lessons may be applicable today as a new disaster, the COVID-19 pandemic, batters Louisiana.

The article is based primarily on secondary sources such as case studies, reports, and news articles. I combine this with my own experience of working at the intersection of the anti-trafficking and social justice movements in Louisiana. As the Coordinator of the Greater New Orleans Human Trafficking Task Force since 2017, I have worked directly with individuals and institutions within both movements that responded during the post-Katrina context and witnessed firsthand the disparate responses to labour abuses. I weave these sources together with the intention of formalising knowledge about interactions between these movements.

\section{Labour Abuse Post-Katrina}

Hurricane Katrina was a catastrophic natural disaster: more than 1,800 people died and millions were impacted by the storm. Half a million housing units in the state of Louisiana were damaged or destroyed. ${ }^{1}$ In New Orleans, the largest city in the state, more than 80 per cent of the city flooded, resulting in damage to 70 per cent of all occupied housing units. However, this was not simply a natural disaster. Human-made conditions in the aftermath of the storm had a severe impact on labourers in the rebuilding period. With governmental oversight failing, contractors and employers provided lower wages, poor workplace safety, and unsanitary living conditions for workers. ${ }^{2}$ Workers routinely experienced 'substandard conditions, homelessness, poverty, toxicity, [and were] under the threat of police and immigration raids, and without any guarantee of a fair

1 A Plyer, 'Facts for Features: Katrina impact', Greater New Orleans Community Data Center, 26 August 2016, retrieved 5 September 2019, https:/ /www.datacenterresearch. org/data-resources/katrina/facts-for-impact.

2 JJ Rosenbaum and R Watson, Broken Levees and Broken Promises: Migrant narratives in their own words, Southern Poverty Law Center Immigrant Justice Project, Montgomery, 2006, https://www.splcenter.org/sites/default/files/d6_legacy_files/downloads/ brokenlevees.pdf. 
day's pay, if they [were] paid at all. They also [faced] structural barriers that [made] it impossible to hold public or private institutions accountable for their mistreatment'. ${ }^{3}$

One study found that 47 per cent of workers reported not receiving their full wages, and 55 per cent did not receive overtime payment. ${ }^{4}$ Rebuilding contracts were defined by complex and confusing chains of contractors and subcontractors, so workers were often unaware of their employers and unable to hold them accountable for misconduct or non-payment. The National Guestworker Alliance (NGA), an organisation focused on protecting immigrant workers, estimates that they served more than 1,000 victims of forced labour and human trafficking between 2007 and 2014. ${ }^{5}$ At least 3,750 potential labour trafficking victims were identified in the Gulf Coast between 2005 and 2010, with 704 of those cases occurring in the New Orleans metropolitan region alone. ${ }^{6}$

It is within this context that new iterations of worker rights and human trafficking movements emerged in Louisiana. There was significant overlap between the vulnerable populations that the two movements aimed to support, and both actively sought to address abusive and exploitative labour practices during this period. However, the largest labour trafficking cases championed during the post-Katrina era were the result of advocacy and efforts by the worker rights movement, not the anti-trafficking movement.

\section{A Tale of Two Movements}

\section{Rebirth of the Worker Rights Movement}

The post-Katrina worker rights movement was established in response to social, economic, and racial injustice in Louisiana following the storm. The failure of government institutions to respond adequately amplified an existing mistrust of authority. Black and Latinx workers who had previously viewed the other as competitors came to appreciate that workers were mistreated across ethnic identities and industries at the grassroots level. Both increased immigration

3 J Browne-Dianis et al., And Injustice for All: Workers' lives in the reconstruction of New Orleans, New Orleans Worker Center for Racial Justice, New Orleans, 2005, p. 8.

4 T Smukler, Working on Faith: A faithful response to worker abuse in New Orleans, Interfaith Worker Justice, Chicago, 2006, p. 10.

5 L Murphy and B Ea, Lonisiana Human Trafficking Report, Modern Slavery Research Project, Loyola University New Orleans, New Orleans, 2014, p. 16.

6 S Hepburn, 'Dispatches: Labor conditions in New Orleans', Americas Quarterly, 2010. 
enforcement and negative law enforcement encounters contributed to growing solidarity, and they began to band together to fight racial discrimination and labour abuses. ${ }^{7}$ These groups focused not just on post-Katrina conditions, but on the broader everyday labour abuses and racial discrimination that existed prior to the storm. The New Orleans Worker Center for Racial Justice (NOWCRJ) was founded in 2006 in response to both the systemic exclusion of Black workers, and the exploitation of migrant workers after Katrina. ${ }^{8}$ Groups like the Alliance of Guestworkers for Dignity (Alliance); Congreso de Jornaleros (Congress of Day Laborers; Congreso), a worker-led project organising migrant workers; and STAND with Dignity (STAND), a grassroots project that organises low-income residents and workers in New Orleans, were also formed after 2006. ${ }^{9}$ The worker rights movement grew into a grassroots network of exploited and disenfranchised workers and ethnic minorities who partnered with civil society. A significant portion of civil society efforts centred on legal services and immigration advocacy that was done on a volunteer, probono, or low-bono basis. This laid the foundation for grassroots responses to issues impacting workers, including racial bias, immigration enforcement, wage theft, and workplace safety conditions.

\section{Establishment of the Anti-Trafficking Movement}

At the time that Hurricane Katrina hit, anti-trafficking work in Louisiana had just begun. This movement, as in other states, focused exclusively on the crime of human trafficking, rather than broader social justice issues like racial justice, worker rights, or immigrant rights. The first human trafficking statute in Louisiana passed in 2005. ${ }^{10}$ In 2006, the US Department of Justice (DOJ) awarded a USD 450,000 grant to the Louisiana Commission on Law Enforcement (LCLE) to establish the Louisiana Human Trafficking Task Force (LAHTTF), which funded state law enforcement such as the Louisiana Sheriff's Association, and victim service providers such as the Metro Center for Community Advocacy. ${ }^{11}$ This task force was established with the intention of addressing the needs of

7 L B Gorman, 'Latino Migrant Labor Strife and Solidarity in Post-Katrina New Orleans, 2005-2007', University of New Orleans Theses and Dissertations, 2009, p. 27.

8 'Adequacy of Labor Law Enforcement in New Orleans', Committee on Domestic Policy of the Committee on Oversight and Government Reform, US House of Representatives, 110th Congress, First Session, 26 June 2007, Serial No. 110-119, Washington D.C., p. 14.

9 'About NOWCRJ', New Orleans Workers' Center for Racial Justice, http://nowcrj. org/about-nowcrj.

10 'Human Trafficking', Louisiana Revised Statute \$14.46.2, eff. 12 June 2005.

11 'Press Release: Attorney General Alberto R. Gonzales Announces Enhanced Programs to Combat Human Trafficking', US Department of Justice, 3 October 2006. 
victims of all forms of trafficking, including migrant workers. ${ }^{12}$

This coalition consisted of high-ranking stakeholders in law enforcement, prosecution, and service providers from across the state. The US Attorney's Offices (USAO) in Baton Rouge and New Orleans established anti-trafficking working groups. The anti-trafficking movement primarily regarded labour exploitation as a product of Hurricane Katrina. As Attorney General Alberto Gonzales stated at a conference in 2006, the government provided increased funding for prosecuting traffickers to 'put a stop to the exploitation and abuse of laborers'. ${ }^{13}$ This was a top-down approach to investigate and prosecute individuals engaged in labour exploitation. The two main focal points were the commercial sexual exploitation of children (CSEC) and extreme cases of forced labour. There were few service providers at the table in the first few years of anti-trafficking work. With the exception of the Catholic Charities Archdiocese of New Orleans (CCANO), a Catholic faith-based non-profit with a robust immigrant services branch, the service providers at the table in the antitrafficking movement were from domestic violence, homeless response, and child protection services. ${ }^{14}$ There were few survivor leaders or people with lived experience managing the anti-trafficking programmes. Affected communities like migrant workers and low-wage local workers did not have a stake in the antitrafficking movement, but were strongly invested in worker rights coalitions. As a result, the anti-trafficking movement's trajectory and actions in the post-Katrina era were significantly different from those of the worker rights movement.

\section{A Perfect Storm: Suspended labour laws and failed governmental protection}

Prior to the storm, wages in Louisiana were far below the national average in the United States ${ }^{15}$ and there were few state laws protecting workers. There existed no state minimum wage or overtime laws, employers were not required

12 A Farrell, J McDevitt, and S Fahy, Understanding and Improving Law Enforcement Responses to Human Trafficking, Northeastern University Institute on Race and Justice, Washington, D.C., 2008, p. 189.

13 Agence France-Presse, 'Louisiana: Human trafficking', The New York Times, 4 October 2006, retrieved 24 October 2019, https://www.nytimes.com/2006/10/04/ us/04brfs-004.html.

14 J Bayhi-Gennaro, Baton Rouge/New Orleans Area Assessment: Identification of domestic minor sex trafficking victims and their access to services, Shared Hope International, PIP Printing, Springfield, April 2008, p. 58.

15 M Muro and R Sohmer, New Orleans after the Storm: Lessons from the past, a plan for the future, Brookings Institution Metropolitan Policy Program, Washington, D.C., 2005, p. 11. 
to provide lunch or rest breaks, and employee benefits were discretionary. Employers could immediately fire an employee for nearly any reason at any time without repercussion. ${ }^{16}$ Given these limited worker rights laws, most legal measures to defend workers were derived from federal laws.

The suspension of federal labour protections after Hurricane Katrina had dire consequences. As one report put it, 'powerful institutional actors shared the post-Katrina landscape and placed workers in situations of disadvantage and inequity. ${ }^{37}$ To address the storm's devastation, the federal government spent approximately USD 75 billion on reconstruction efforts. ${ }^{18}$ However, President George W. Bush's administration suspended key worker protection laws with the intention of expediting the rebuilding process. Employers could bypass a requirement to confirm their employees were authorised to work in the US. Contractors and subcontractors hired by the government to complete construction projects were paying as low as the federal minimum wage of USD 5.15 per hour, which was USD 4.00 less than the prevailing wage in Louisiana. The Department of Labor (DOL), the agency mandated to enforce more than 180 federal workplace laws, suspended a provision which required contractors to submit written affirmative action and non-discrimination plans. ${ }^{19}$ The Occupational Safety and Health Administration (OSHA) suspended job safety and health standard enforcement in hurricane-impacted parishes for several months. ${ }^{20}$ Though these workplace protections were reinstated by the end of 2005, the majority of federal reconstruction contracts were awarded during the few months in which these laws were suspended. As a result, many contractors were not obligated to comply with basic workplace standards.

Labour regulation systems failed to hold exploitative employers accountable after the storm. As one advocate told Congress, 'the DOL lacked the capacity and strategic direction to deal with this crisis. ${ }^{21}$ In the wake of Katrina, the DOL became the lead agency investigating workplace violations but its investigations drastically decreased. In 2006, the New Orleans DOL office conducted merely forty-four investigations into workplace labour violations-down from seventy

16 'Contract of servant terminable at will of parties', Louisiana Civil Code Art. 2024, Acts 1984, No. 331, \1, eff. 1 January 1985.

17 J Browne-Dianis et al., p. 4.

18 B Alpert, '\$120 in Katrina Federal Relief Wasn’t Always Assured’, The Times-Picayune, 21 August 2015, retrieved 22 October 2019, https://www.nola.com/news/ article_338b3dd9-30e5-576d-b52a-d91ee07a499a.html.

19 'Guidance Applicable to Acquisitions for Hurricane Katrina Rescue and Relief Efforts to include Class Deviations from Federal Acquisition Regulation (FAR)', US Department of Homeland Security, 28 October 2005.

20 Ibid.

21 'Adequacy of Labor Law Enforcement in New Orleans', p. 10. 
in 2004. ${ }^{22}$ Furthermore, it employed only one Spanish-speaking investigator, and it took more than a year to hire a second one. ${ }^{23}$ Organisers working with labourers claimed that there were no after-hours reporting options. ${ }^{24}$

More fundamentally, many workers did not know that the DOL existed to protect their rights, ${ }^{25}$ while the DOL maintained until 2008 that it did not have the authority to enforce H-2B Guestworker Program regulations. ${ }^{26}$ The substandard response of the DOL, coupled with the fear of blacklisting or deportation, left guestworkers vulnerable to abuse. ${ }^{27}$ At the same time, the Louisiana Workforce Commission (formerly called 'Louisiana Works: Department of Labor') did not have a division that handled wage and hour claims because Louisiana does not have a minimum wage law $^{28}$. Its role was limited by the lack of state worker protection laws in place that it could enforce. In short, workplace protection agencies failed to provide adequate oversight of workplace violations.

\section{Worker Rights Movement Response}

The worker rights movement responded to substandard labour conditions, suspended worker protection, and the ineffectiveness of state agencies by empowering workers through a variety of community-based activities. These included legal services, know-your-rights training, and leadership opportunities. The movement also actively advocated for improved legislation for workers. In 2009, for example, members of the Alliance of Guestworkers for Dignity and the NOWCRJ spoke in front of the House Oversight and Government Reform Committee at a hearing on the $\mathrm{H}-2 \mathrm{~B}$ Guestworker Program. ${ }^{29}$

22 Hepburn, 2009.

23 'Adequacy of Labor Law Enforcement in New Orleans', p. 5.

24 Ibid., p. 12.

25 Smukler, p. 5.

26 Hepburn, 2009. H-2A and H-2B visas allow immigrants temporary agricultural and non-agricultural work with a single employer if a sponsoring employer can prove US citizens are unavailable. Guestworkers are highly vulnerable because their status is tied to a single employer, and the employer can place workers on a blacklist that bars them from being hired in the US in the future.

27 Browne-Dianis et al., pp. 45-49.

28 Louisiana does not have an established state minimum wage, therefore employers are required to follow the federal minimum wage rate established under the Fair Labor Standards Act.

29 'The H-2B Guestworker Program and Improving the Department of Labor's Enforcement of the Rights of Guestworkers', House Oversight and Government Reform Committee, Domestic Policy Subcommittee, US House of Representatives, Congress, 21 April 2009. 
As the years passed, organising efforts contributed to successful worker campaigns. One example was the C.J.'s Seafood case. The movement banded together to protest worker treatment at C.J.'s Seafood, a crawfish provider in Breaux Bridge, Louisiana that supplied seafood to major retailers such as Walmart. Workers who came to C.J.'s through the H-2B Guestworker Program were subjected to terrible working conditions. Some were forced to work sixteen to twenty-four hours per day or more than eighty hours per week, and they were threatened with violence if they did not work fast enough. ${ }^{30}$ Workers began holding strikes and rallies in the Greater New Orleans area based on their training from the NOWCRJ and NGA. Representatives of the service industry, unions, community groups, and immigrant rights organisations organised to strike against employers' mistreatment of both immigrant and American workers. They filed multiple complaints with regulatory agencies and demanded reform in Walmart's labour supply chain standards. The NGA released a list of Walmart food suppliers with federal work citations to try and pressure the corporation to more strictly comply with work standards. The list generated investigations by Walmart, the DOL, and the OSHA. Walmart ended its relationship with the seafood company a month after the campaign started, and C.J.'s was fined nearly USD 250,000 for its workplace safety and wage violations. This case exemplified the way that workers organised at the grassroots level to fight labour violations.

\section{Anti-Trafficking Movement Response}

Meanwhile, the anti-trafficking movement was focused on responding to severe forms of labour abuse through criminal justice structures. The LAHTTF was mandated to address both trafficking for the purpose of forced labour and commercial sexual exploitation. In the years following its establishment it created strong investigative and prosecutorial frameworks for its members to respond to commercial sexual exploitation, with a specific emphasis on minors. However, the labour trafficking response proved to be ineffective. One of the main challenges that they faced was to establish evidence of force, fraud, or coercion to prosecute alleged abusers. In some cases, a lack of awareness of the types of coercion that could compel someone to stay in conditions of abuse became a barrier to pursuing cases. Lack of experience or knowledge also meant that few cases emerged. According to one survey in 2008, only 4.2 per cent of law enforcement in Louisiana had ever investigated a human trafficking case. ${ }^{31}$ Ongoing worker mistrust of law enforcement led vulnerable people to choose not to cooperate with investigations, leaving agents struggling to understand why workers' representatives did not refer cases to them.

30 S Greenhouse, 'Wal-Mart Suspends Supplier of Seafood', The New York Times, 29 June 2012, retrieved 21 October 2019, https:/ /www.nytimes.com/2012/06/30/business/ wal-mart-suspends-seafood-supplier-over-work-conditions.html.

31 Farrell et al., p. 50. 
Despite the challenges for criminal justice responses to labour exploitation, there were at least nine federal human trafficking cases born out of the postKatrina reconstruction era, all of which involved immigrant labourers. ${ }^{32}$ The USAO brought several major labour trafficking cases to court.

One example of a successful federal court case originating in Louisiana was the case of Nunag-Tañedo et al. v. East Baton Rouge Parish School Board et al. When school districts had a difficult time finding enough teachers after the storm, they turned to labour recruiters to find guestworkers. ${ }^{33}$ Universal Placement International (UPI) supplied more than 360 Philippine teachers to a number of school districts. Those teachers paid exorbitant recruitment fees and were subject to a variety of other fees once they arrived in Louisiana. Their visas and passports were confiscated, and they were threatened with deportation if they spoke out against the horrific financial abuse and substandard living conditions. Eventually some of the workers fought back and sought support from legal service agencies to hold the labour recruiters and the school districts that hired them accountable for the abuse. The teachers eventually won a USD 4.5 million class action suit against the school district to recover damages and an injunctive relief against the fraudulent recruiters. ${ }^{34}$ In addition, the Louisiana Workforce Commission awarded the workers a return of the money that UPI had confiscated from them. ${ }^{35}$

However, in many other instances, prosecutors required external pressure to take on cases, as illustrated by the case of Signal International. In 2005, hundreds of guestworkers from India came to the Gulf Coast in Pascagoula, Mississippi to repair oil rigs damaged by Hurricane Katrina. The workers paid thousands of dollars in recruitment fees because they were promised pathways to citizenship. Upon arrival, they were given $\mathrm{H}-2 \mathrm{~B}$ visas, segregated by racial groups, and forced to live in a guarded work camp with substandard housing conditions. Their passports and visas were retained, and they were 'threatened, coerced and defrauded ... believing that if they did not work for Signal under the auspices of temporary and Signal-restricted H-2B guestworker visas, they would suffer

32 S Hepburn and R Simon, 'United States', in Human Trafficking Around the World: Hidden in plain sight, Columbia University Press, New York, 2013, pp. 13-43.

33 Nunag Tanedo et al. v. East Baton Rouge Parish School Board et al. (8:10-cv-01172), District Court, Central District of California, filed 5 August 2010.

34 Ibid.

35 S Dick, 'In RE: Complaint of the Louisiana Federation of Teachers and the American Federation of Teachers $\mathrm{O} / \mathrm{B} / \mathrm{O}$ certain Filipino teacher local members: Findings and Administrative Determination of the Louisiana Workforce Commission', Louisiana Workforce Commission, 14 April 2020, http://la.aft.org/files/article_assets/079D5835BB59-61D7-4D0AE56F0C4856AD.pdf. 
abuse'. ${ }^{36}$ Legal service providers and workers attempted to garner support from federal law enforcement and prosecutorial entities in New Orleans to no avail. The Homeland Security Office in New Orleans was even accused of conspiring with Signal International to conduct immigration enforcement operations after workers demanded improved working conditions.

Members of the LAHT'TF and other anti-trafficking working groups believed that there was not enough evidence to prove that the workers' experiences rose to the level of severe forms of human trafficking. The workers eventually conducted a high-profile march and public hunger strike that sparked international media attention. As a result, the DOL, the Equal Employment Opportunity Commission (EEOC), the OSHA, and the DOJ offered to open or reopen investigations into the claims of the workers. In 2012, a US district court found Signal International, a New Orleans lawyer, and an Indian labour recruiter guilty of labour trafficking, fraud, racketeering, and discrimination under the Trafficking Victim Protection Act and the Racketeering Influenced and Corrupt Organizations Act. While the recruiter and lawyer were each required to pay USD 915,000 , Signal International was forced to pay USD 12 million in damages to the workers. ${ }^{37}$

The anti-trafficking movement did not actively advocate or respond to labour protection rollbacks or enforcement failures. Some members of the movement did not recognise the significance of these regulative policies and how they made workers vulnerable to abuse. Anti-trafficking service providers understood that race, immigration status, and socioeconomic status impacted a person's vulnerability to labour exploitation. However, they did not engage in advocacy on those issues as they related to workers. Worker abuse outside of the framework of illegal exploitation, such as forced labour or coerced labour, could not be addressed within criminal anti-trafficking investigations.

In addition to these institutional constraints, there were further complications associated with how the concept of human trafficking was understood and applied. Many within the criminal justice framework saw trafficking as victimisation occurring 'in a vacuum', devoid of historical, cultural, or regulatory context. This simplistic view saw the crime as a result of the acts of an abuser,

36 David et al. v. Signal International, LLC et al., US District Court, Eastern District of Louisiana, pp. 2-3, https://cases.justia.com/federal/district-courts/louisiana/ laedce/2:2008cv01220/124306/1947/0.pdf.

37 Ibid.; see also 'David, et al. v. Signal International, LLC, et al.', American Civil Liberties Union, 29 May 2013, https:/ / www.aclu.org/cases/david-et-al-v-signal-internationalllc-et-al; and 'Signal International lawsuits (re trafficking of Indian workers in USA)', Business and Human Rights Resource Centre, n.d., https:/ / www.business-humanrights. org/en/signal-international-lawsuits-re-trafficking-of-indian-workers-in-usa. 
rather than of conditions that manufactured the patterns of vulnerability within which exploitation occurred. Other figures in the movement were governmental agencies with limited means and flexibility to publicly disagree with federal policies, even if specific individuals may have recognised the harms associated with the suspension of labour protections.

It is worth noting that these groups were more pro-active when it came to issues related to CSEC. Members of the anti-trafficking movement were actively engaging in advocacy around the vulnerability of individuals in sex industries and of children who experience sexual abuse. In 2013, for example, anti-trafficking agencies supported the passage of safe harbour legislation, a policy of not charging people under the age of eighteen with prostitution-related offences. ${ }^{38}$ This demonstrated that the anti-trafficking movement had the capacity to push back against established criminal justice practices for prioritised policy areas. There was a political investment among anti-trafficking actors when it came to policy changes to prevent CSEC, but the same kind of political will was absent for policy changes around labour exploitation.

\section{Scapegoating: Cultural rifts and political tension}

In addition to the erosion of worker protections, racial tension between native Louisianans and migrant workers increased during the rebuilding period. Reconstruction required a large number of workers, but more than one million displaced Gulf Coast residents did not return. ${ }^{39}$ From August to September 2005, the number of Louisianan workers employed in construction and related industries dropped from 40,100 to $22,500 . .^{40}$ In New Orleans, the storm disproportionately displaced poor and Black working class communities because they mostly lived in the city's lower-lying parts that had flooded. ${ }^{41}$

Migrant workers were willing to work for even lower pay than Louisianans, so employers began actively recruiting them. Migrants came to Louisiana en masse seeking employment in the burgeoning construction industry. The Latinx population in Greater New Orleans doubled after the storm: 45 per cent of

38 'Safe Harbor for Sexually Exploited Children', Louisiana Children's Code, Article 725, Chapter 20, No. 429, \3, eff. 24 June 2013.

39 Plyer.

40 'American Community Survey Data', US Census Bureau, 2005.

41 Muro and Sohmer, pp. 16-17. 
construction workers were Latinx, of whom 54 per cent were undocumented. ${ }^{42}$ Unscrupulous employers with federal contracts to rebuild took advantage of the suspension of labour regulations by hiring migrant labourers rather than local residents. Contractors found that migrants were willing to work for less and to endure harsher work conditions because of their fear of law enforcement and immigration retaliation. As the Southern Poverty Law Center pointed out, 'The recruitment of guestworkers is a lucrative business for the companies that help U.S. employers obtain cheap foreign labor. ${ }^{43}$ Emboldened by the lack of governmental oversight, contractors created a 'race to the bottom' for labourers. One case exemplifying this type of abuse is that of Decatur Hotels in New Orleans, where workers were fired and replaced by undocumented workers who earned USD 2 less per hour. Eventually these employees were also replaced by guestworkers on $\mathrm{H}-2 \mathrm{~B}$ visas for an hourly wage of USD 4 less. ${ }^{44}$ Ultimately, those guestworkers were in turn threatened with deportation for demanding better working conditions. These labour practices placed significant strain on worker solidarity and pitted ethnic groups against each other.

Political tension ignited as migrant workers became scapegoats for skyrocketing unemployment rates, which rose to 11.4 per cent by September $2005 .{ }^{45}$ Louisiana residents demanded an explanation for high unemployment rates, poor wages, and unsafe working conditions. As a result, political figures positioned migrant labourers as culprits for the suffering of Louisianan labourers. Responding to public sentiment, Senator Mary Landrieu declared that 'it is unconscionable that illegal workers would be brought into Louisiana aggravating our employment crisis and depressing earnings for our workers. ${ }^{46}$ Political figures across the state called on the US Department of Homeland Security's (DHS) Immigration and Customs Enforcement (ICE) to dispatch immigration enforcement throughout the state to 'institute a zero tolerance policy for the use of illegal workers. ${ }^{347}$

42 L Fletcher et al., Rebuilding After Katrina: A population-based study of labor and buman rights in New Orleans, International Human Rights Law Clinic University of California Berkeley, Human Rights Center University of California Berkeley, and Payson Center for International Development and Technology Transfer Tulane University, June 2006, ISBN: 0-9760677-2, p. 9.

43 M Bauer, Close to Slavery: Guestworkerprograms in the United States, Southern Poverty Law Center, 2007, revised 2013, p. 10, https://www.splcenter.org/sites/default/files/ d6_legacy_files/downloads/publication/SPLC-Close-to-Slavery-2013.pdf.

44 Hepburn, 2009.

45 'Regional and State Employment and Unemployment Summary', Bureau of Labor Statistics, US Department of Labor, 21 October 2005.

46 Letter from Senator M Landrieu to Secretary M Chertoff, Secretary of US Department of Homeland Security, dated 18 October 2005.

47 Ibid. 
There was little recognition that federal policies had essentially encouraged the employment of migrants in the first place.

This kind of discourse reinforced ideas that migrants caused Black labourers' exclusion from rebuilding, even though there was evidence that Black labourers had been systematically excluded by employers and contractors. ${ }^{48}$ Louisianan workers and foreign workers 'suffer[ed] from a profound lack of awareness of and exposure to each others' [sic] plight. African Americans [did] not know that governmental policy and practice pushed workers into exploitative jobs. Immigrants [did] not know that governmental action and inaction [had] systematically excluded African Americans from work in New Orleans after Katrina. ${ }^{39}$ By weaving these narratives together, Louisiana residents blamed migrant workers for the outcomes of systemic racism and poor policy rather than the failure of systems meant to protect workers.

Increased immigration enforcement started nearly as soon as foreign workers began to arrive. Merely days after the government relaxed requirements related to the prevention of hiring undocumented migrants, the DHS announced that it had deployed 750 officials to the Gulf Coast, including Detention and Removal Operations staff. ${ }^{50} \mathrm{ICE}$ and local law enforcement would frequent locations where migrant workers congregated. Workers across race and industry reported numerous incidents of law enforcement abuse and violence at the hands of police and immigration authorities. Employers used the fear of deportation to compel migrant workers to stay in exploitative conditions. ${ }^{51}$ Worker rights organisations decried the use of immigration enforcement, while key law enforcement agencies within the anti-trafficking network were engaging in immigration enforcement. In some cases, workers alleged that ICE coordinated with employers to arrest migrant workers when they spoke out against abusive employers or when payday arrived. Claims of law enforcement and immigration enforcement collaboration to benefit employers were rampant. ${ }^{52}$ Both Black and immigrant labourers reported harassment on the street from law enforcement. ${ }^{53}$ This added to the climate of fear in which workers were afraid to hold their abusers accountable through criminal justice frameworks.

\footnotetext{
48 Browne-Dianis et al., p. 10.

49 Ibid.

50 'Press Release: ICE Law Enforcement Support Proves Critical to Hurricane Rescue and Security Efforts', US Immigration and Customs Enforcement, 8 September 2005.

51 Browne-Dianis et al.

52 Ibid., p. 45.

$53 \quad$ Ibid., p. 8.
} 


\title{
Worker Rights Movement Response
}

The goal of the worker rights movement was to collaborate to 'build a new freedom movement: multi-racial; committed to racial, gender, and immigrant justice; and dedicated to building power at the intersection of race and the economy.' As Saket Soni, labour leader and founder of the NOWCRJ explained,

\begin{abstract}
STAND with Dignity_yes, they're fighting for inclusion and advancement but they're also fighting for racial justice. To overcome exclusion and win dignified decent work, they have to push against the criminalization of African Americans... Similarly, the Congress of Day Labourers wants to win dignified work but also wants to stop deportations in a country that asks for immigrants to work but then criminalizes them when they seek out work. These movements are intertwined and in many ways are one movement... human rights, civil rights and labor rights have always been very deeply intertwined, and they still are now. ${ }^{54}$
\end{abstract}

They attempted to address racial tensions between member groups by creating a multi-ethnic space to discuss shared experiences such as wage theft. The worker rights movement demonstrated against immigration enforcement, wage theft, and housing shortages. Representatives of the movement participated in Congressional hearings to discuss the failures of the DOL to protect workers. They worked together to bring back confiscated passports and pressure employers to enact safer working conditions for labourers. ${ }^{55}$ Attorneys joined the movement to provide free and low-cost legal services to exploited workers. Between 2006 and 2011, the Wage Claim Clinic, an initiative of the Loyola University New Orleans College of Law's Workplace Justice Project, tried nearly 1,400 cases, won more than 60 wage-theft cases, and recovered hundreds of thousands of dollars in back wages. ${ }^{56}$ Additionally, members of the worker rights movement facilitated engagement with law enforcement for exploited labourers to seek justice while mitigating risk of deportation. When the owner of Louisiana Labor, LLC withheld his workers' passports, for example, local residents and members of the Guestworker Alliance worked together to ensure that the Calcasieu Parish Sheriff's Office retrieved the passports and returned

54 A Lee, 'Organizing for a True Reconstruction in the Gulf Coast: An interview with labor leader Saket Soni', Facing South, 26 August 2015, retrieved 27 July 2020, https:/ / www.facingsouth.org/2015/08/organizing-for-a-true-reconstruction-in-the-gulf-c.

55 Hepburn, 2009.

56 Hepburn and Simon, pp. 13-43; '2011 Provost Report: Loyola University New Orleans', Loyola University New Orleans, 23 March 2012, pp. 20-21. 
them to the workers without taking any negative immigration actions. ${ }^{57}$

In the case of Signal International, mentioned earlier, multi-ethnic organising was a cornerstone of the workers' success. On 9 March 2007, 'Signal, in coordination with [private security guards], attempted to forcibly and unlawfully deport [workers] ... in retaliation for speaking out against discriminatory conditions in Signal's labour camp'. ${ }^{58}$ After a lack of action by local law enforcement and federal agencies to hold Signal accountable, more than 100 of the workers went on strike by marching from New Orleans to Washington, DC. They marched to demand just treatment and freedom from the exploitative labour conditions they faced. As the labourers travelled to Washington DC, Black workers and other allies travelled alongside the guestworkers to protect them from immigration enforcement. ${ }^{59}$ African American religious leaders in North Carolina supported efforts to get congressional representatives interested, and a historically Black church in Atlanta provided sanctuary to the strikers after advocates asserted that ICE was following the marchers. ${ }^{60}$

Another example of the successful use of multi-ethnic organising is the case of Bimbo's Best Produce. Workers brought to Louisiana on H-2A visas faced horrific conditions after Bimbo's put them to work in some strawberry fields. Their immigration documents were confiscated, they faced physical and emotional abuse, and were threatened with deportation or blacklisting if they attempted to leave. However, 'when members of African-American and immigrant communities came forward to protect guestworkers, the guestworkers escaped the slave-like conditions of the Defendant's strawberry plantation'. ${ }^{61}$ Cases like this exemplify how collective, community-based organising served as an effective strategy for workers to respond to their abuses. While tensions between different groups never entirely disappeared, the worker rights movement was able to build a broad coalition which helped to bring labourers together.

57 Hepburn, 2009.

58 Ibid., p. 3.

59 JJ Rosenbaum, et al., 'A Special Message to NGA Members on the Signal Victory', National Guestworker New Orleans Workers Center, 21 February 2015, http:/ /www. guestworkeralliance.org/2015/02/a-special-message-to-nga-members-on-the-signalvictory-2-21-15.

60 Ibid.

${ }^{61}$ Antonio-Morales et al. vs. Bimbo's Best Produce et al., US District Court for the Eastern District of Louisiana, 10 December 2008, http://nowcrj.org/wp-content/uploads/ 2016/09/antonio-morales-v-bimbos-best-produce-085105.pdf. 
Anti-Trafficking Movement Response

Leaders of the anti-trafficking movement were conspicuously absent from the initiatives undertaken by the worker rights movement described above. This was partly because they were not necessarily welcome. Representatives of law enforcement and government agencies were viewed as complicit in systems of oppression, to the point where they were sometimes accused of directly harming vulnerable people. Some non-profit immigrant service providers, however, were able to successfully navigate both the anti-trafficking and worker rights worlds. CCANO provided services to immigrants and distanced itself from law enforcement responses and case referrals. From 2009 to 2011, CCANO is estimated to have served approximately 125 people alleging they experienced labour trafficking. ${ }^{6}$ However, this was the exception among anti-trafficking entities.

The anti-trafficking movement as a whole did not actively address systemic racism, immigrant rights, or other issues central to the interests of the worker rights movement. There is a body of literature that shows how the broader anti-trafficking movement has failed to take account of racism, and in some cases, perpetuates it. ${ }^{63}$ This was also the case in Louisiana's anti-trafficking movement.

Some law enforcement agencies who participated in anti-trafficking work were actively engaging in activities that contributed to a climate of fear for labourers. Throughout Louisiana, law enforcement officials were deputised by ICE to conduct immigration enforcement. In Greater New Orleans, the Jefferson Parish Sheriff's Office, the Orleans Parish Sheriff's Office, and ICE were all members of the USAO's New Orleans Human Trafficking Working Group (NOHTWG), which also conducted immigration enforcement. Attempting to serve non-citizen trafficking survivors while simultaneously conducting immigration enforcement on workplaces created mixed messages for foreign victims of crime. These law enforcement agencies were inadvertently reinforcing mechanisms that abusive employers used to control vulnerable workers. The fear of deportation became a barrier for foreign workers to report their experiences of exploitation. ${ }^{64}$

62 Murphy and Ea, p. 16.

63 See generally: T P Woods, 'The Antiblackness of "Modern-day Slavery” Abolitionism', openDemocracy, 10 October 2014, retrieved 28 May 2020, https:/ / www.opendemocracy. net/en/beyond-trafficking-and-slavery/antiblackness-of-modernday-slaveryabolitionism; L Beutin, 'Black Suffering for/from Anti-trafficking Advocacy', AntiTrafficking Review, issue 9, 2017, pp. 14-30, https://doi.org/10.14197/atr.20121792. 


\section{Lessons of the Past}

In recent years, both the anti-trafficking and the worker rights movement have largely continued the trajectories that began post-Katrina. Given that human trafficking intersects with worker rights and criminal justice responses, there was at least hypothetically a window for a novel response to labour abuses which saw the worker rights and anti-trafficking movements collaborating on issues of mutual concern. As we have seen, this potential was not realised in practice. For the worker rights movement, the storm gave rise to a multi-racial coalition to combat shared experiences of labour abuse and catalysed cooperation among impacted communities. While the anti-trafficking movement ostensibly shared similar concerns, their institutional positions and heavy investment in criminal justice models created barriers to collaboration and effective intervention. This mistrust led members of the anti-trafficking movement to view worker rights groups as unwilling to cooperate. Actors within the anti-trafficking movement felt that the worker rights movement could be difficult to work with because of its decentralised and worker-driven approach, which did not align with their topdown institutionalised approach. Meanwhile, worker rights movement members perceived key members of the anti-trafficking movement as complicit in systems of oppression and systemic racism, and as a result did not regard anti-trafficking groups as safe allies. Overall, these factors contributed to a stark divide between the two movements' efforts to address labour abuses.

Today, the worker rights movement continues organising through an intersectional lens, acknowledging that oppression and abuse happen across identity lines in the context of race and socio-economic status. Since 2015, the movement has protested against a variety of issues, including the deportation of migrants, police brutality, and mass incarceration. ${ }^{65}$ In 2016, the movement celebrated a change in New Orleans Police Department policy to stop sharing immigration-related information with ICE. In 2017, Black labourers successfully campaigned to get a USD 10.55 per hour living wage ordinance for city workers. ${ }^{66}$ In July 2020, the NOWCRJ sued the DOL for removing labour protections for immigrant victims or witnesses of workplace crimes and

65 A Woodward, 'Sen. Kennedy Calls on Mayor Cantrell to "Undo" NOPD Immigration Policy', Gambit, 9 August 2019, https://www.nola.com/gambit/news/article_ c38a3ed4-5025-5afe-a0d6-c4e9f5081129.html; A Woodward, “'It's Time for Action”: New Orleans joins nationwide call to abolish ICE and reunite families', Gambit, 30 June 2018, retrieved 29 July 2020, https://www.nola.com/gambit/news/the_latest/ article_35613e44-b43c-55b5-9a3b-f4dac9de435b.html.

66 A Woodward, 'N.O. Council Passes “Living Wage” Law', New Orleans Workers' Center for Racial Justice, 10 August 2015, http:/ / nowcrj.org/2015/08/10/n-O-councilpasses-living-wage-law-gambit-81015. 
human trafficking. ${ }^{67}$ The worker rights movement has achieved community-level victories, though the system-level changes needed for broader protection of labourers have perhaps eluded them thus far.

The anti-trafficking movement has expanded dramatically to include more service providers and have more options outside of the criminal justice system. Over the past decade, for example, the availability of services such as mentorship, housing assistance, and mental health support have increased for people who have experienced human trafficking. The anti-trafficking movement has also advocated to address vulnerabilities associated with trafficking of individuals in the sex industry, such as reforms to improve child protection systems, early childhood social services, and social services for sexual violence survivors. However, calls for racial justice, immigration reform, or labour rights have been conspicuously absent from their advocacy efforts. The movement has actively attempted to include more survivor leaders in its decision-making, but progress remains slow. To date, the Governor's Human Trafficking Prevention Commission and Advisory Board does not have a designated member from an organisation that primarily serves foreign nationals or labour trafficking survivors. ${ }^{68}$

Fifteen years after Katrina, it is clear that the roots of these movements have defined their trajectories. Despite the connection between labour rights and antitrafficking issues, the two movements have not successfully collaborated. Some individuals within each of these movements see the potential for partnership, but the process of building trust will depend largely on the anti-trafficking movement's ability to engage with workers and reconsider how heavily it relies on the criminal justice system. Across the country, individual entities have begun to step forward to denounce anti-trafficking efforts that do not take an active role in promoting the rights of migrants, ethnic minorities, and workers. ${ }^{69}$ Since 2017, leaders within the anti-trafficking movement in some communities, like New Orleans, have invited workers and organisations representing workers to educate members of the anti-trafficking movement on issues that workers face in Louisiana. However, without addressing institutional racism, immigration policy, and workers' rights, the anti-trafficking movement will continue to be siloed from the efforts of the worker rights movement. The worker rights

${ }^{67}$ New Orleans Worker Center for Racial Justice v. United States Department of Labor, US District Court for the District of Columbia, 7 July 2020.

68 Executive Summary for the 2018 Annual Report, Louisiana Human Trafficking Prevention Commission and Advisory Board, Baton Rouge, 14 March 2019, http:/ gov.louisiana. gov/assets/Programs/ChildrensCabinet/HTPC-2018-Exec-Summary-AnnualReport.pdf.

69 M Gira Grant, 'The Trump Administration Finally Broke the Anti-trafficking Movement', The New Republic, 18 February 2020, https://newrepublic.com/ article/156579/trump-administration-finally-broke-anti-trafficking-movement. 
movement has demonstrated the ways in which workers from different cultural, ethnic, and professional backgrounds can coalesce to fight for broader social justice issues.

While Katrina did bring new and extraordinary challenges, it also highlighted the deep, systemic roots of everyday labour abuses. Rollback of federal worker protection laws had horrific outcomes, but then-existing state labour protection laws had already put workers at a disadvantage. Historic racism and cultural tensions among residents remain to this day. By responding only to the most egregious cases of abuse, enforcement agencies have failed to address the more widespread, 'everyday abuses' that workers experience. Certain forms of enforcement, such as immigration enforcement, have made the problems worse by silencing victims and making impacted communities less likely to come forward to report abuse. The guestworker visa program has not been reformed and continues to be a source of labour abuse and human trafficking to this day. These issues are deeply rooted and continue to make workers vulnerable to a broad spectrum of labour abuse.

\section{Conclusion: History repeating}

Fifteen years post-Katrina, many of the conditions highlighted by the storm remain unremedied. This is particularly concerning as a new disaster, the COVID-19 pandemic, ravages Louisiana. Parallels between the two disasters have already been drawn by residents and government officials alike. ${ }^{70}$ Louisiana has been particularly hard hit by the virus: as of 1 July 2020 , more than 61,561 Louisianans have been diagnosed with the virus and at least 3,147 have died. ${ }^{71}$ The Latinx and Black communities have been disproportionately impacted by COVID-19, both where health disparities and workplace safety issues are concerned. ${ }^{72}$ In New Orleans, allegations of substandard labour conditions during the pandemic echo the experiences of workers who lived in the aftermath of Katrina.

70 See generally: D Sevastopulo and B Greeley, 'Fifteen Years after Katrina, New Orleans Battles Coronavirus Storm', Financial Times, 3 April 2020, https://www.ft.com/ content/28123b5c-837e-4357-9477-3454c840059c $\Delta$.

71 Louisiana Coronavirus (COVID-19) Information, Louisiana Department of Health, retrieved 1 July 2020, http://ldh.la.gov/Coronavirus.

72 R Santana, 'New Orleans: Concern over coronavirus in Hispanic community', AP News, 25 May 2020, https://apnews.com/54c42dcb030cdc8f34ce384d7ad9f86c; K Curth, 'New Orleans Officials Say COVID-19 Disproportionately Affecting Hispanic and Latino Community', Fox 8 WVUE New Orleans, 20 May 2020, https://www. fox8live.com/2020/05/20/new-orleans-officials-say-covid-disproportionatelyaffecting-hispanic-latino-community. 
As of July 2020, the Louisiana Department of Health (LDH) had identified more than 130 outbreaks, most of which occurred in workplaces such as food processing and industrial settings. ${ }^{73}$ Sanitation workers in New Orleans have begun a strike to demand improved safety, increased wages, and hazard pay to accommodate their exposure to the virus. ${ }^{74}$ Hospitality workers are on strike to demand adequate pay and workplace safety because they have been required to return to work as the state is reopening. ${ }^{75}$ Within the seafood processing industry, guestworkers are decrying unsafe living conditions and a lack of workplace safety measures. ${ }^{76}$ On 18 May 2020, the LDH announced it was investigating three seafood processing facilities where more than 100 workers had tested positive for COVID-19. ${ }^{77}$ Reports from the field are already emerging of employers using the high unemployment to control labourers and keep them in exploitative work situations. On top of all this, racial tensions are at a boiling point in the US. The death of Black Americans at the hands of law enforcement - including George Floyd, an unarmed Black man killed by police officers in Minneapolis, Minnesota - have ignited worldwide protests calling for an end to police brutality and racism. ${ }^{78}$ Thousands of Louisianans have taken to the streets in solidarity with these movements.

73 'COVID-19 Outbreaks', Louisiana Department of Health, 8 July 2020, http://ldh. la.gov/index.cfm/page/3997.

74 M Sledge, 'New Orleans Sanitation Workers, Police Demand Hazard Pay during Coronavirus Pandemic', The Times Picayune and The New Orleans Advocate, 18 May 2020, https://www.nola.com/news/coronavirus/article_e96a4e14-995a-11ea-87edcf029941ee9a.html.

75 M I Stein, 'Some New Orleans Workers Scramble to Organize as They're Pushed Back into Frontline Jobs', The Lens, 29 May 2020, https://thelensnola.org/2020/05/29/ some-new-orleans-workers-scramble-to-organize-as-theyre-pushed-back-intofrontline-jobs; M I Stein, “We're Having to Choose to Put Ourselves at Tisk”: Tough decisions for workers as city, state reopen', The Lens, 15 May 2020, https:/ thelensnola. org/2020/05/15/were-having-to-choose-to-put-ourselves-at-risk-tough-decisionsfor-workers-as-city-state-reopen.

76 S Karlin, "Elbow to Elbow": Coronavirus outbreaks at crawfish plants highlight migrants' working conditions', The Advocate, 19 May 2020, https://www.theadvocate. com/baton_rouge/news/coronavirus/article_0bd1c0c4-9a26-11ea-b7219f557eacd530.html.

77 T Lux, 'Unsurprised by Outbreaks at Crawfish Facilities, Experts and Advocates Warn “It Will Happen Again”", WWNO, 22 May 2020, https://www.wwno.org/post/ unsurprised-outbreaks-crawfish-facilities-experts-and-advocates-warn-it-will-happenagain.

78 J Hernandez and B Mueller, 'Global Anger Grows Over a Death in Minneapolis', The New York. Times, 1 June 2020, https://www.nytimes.com/2020/06/01/world/asia/ george-floyd-protest-global.html. 
Worker rights groups are already emerging to support strikes, demonstrations, fundraising, and advocacy efforts of labourers. Meanwhile, the anti-trafficking movement has laid somewhat dormant. The criminal justice system has been on hold: federal and local courts were closed for weeks, law enforcement officials limited investigations to essential operations - which do not include proactive human trafficking investigations-and service providers have shuttered inperson services to victims of crime.

The COVID-19 pandemic has not yet reached its zenith, and the extent of the economic fallout resulting from the crisis remains undetermined. It is possible that conditions of widespread labour abuse, similar to that of the post-Katrina era, will be catalysed by the pandemic. With unemployment rates higher than they were in the post-Katrina era-skyrocketing as high as 15.1 per cent in April $2020^{79}$ — issues around employment and workplace safety are increasingly important. This crisis offers the anti-trafficking movement an opportunity to work alongside the worker rights movement for an improved collaborative response to labour abuse in Louisiana-one that applies the lessons from the post-Katrina era to the present challenges facing workers and migrants.

Leanne McCallum is the Task Force Coordinator for the Greater New Orleans Human Trafficking Task Force. In this position, she facilitates multidisciplinary collaboration between law enforcement, social services, and community members to enhance evidence-based, human rights-driven anti-trafficking responses. Prior to that, she worked at the University of Denver's Human Trafficking Center as the Human Trafficking Index Project Manager. She earned an MA in International Studies from the Josef Korbel School of International Studies at the University of Denver and a BA in International Relations with a minor in Political Science from Linfield College in McMinnville, Oregon. Email: lmccallum@nolatrafficking.org

79 'Louisiana Economy at a Glance: Unemployment data', US Bureau of Labor Statistics, 20 April 2020, https://www.bls.gov/eag/eag.la.htm. 